\title{
Balance sheet effects and the choice of exchange rate regime in developing countries
}

\author{
Michael Bleaney ${ }^{\mathrm{a} *}$ and Manuela Francisco ${ }^{\mathrm{b}}$ \\ ${ }^{a}$ School of Economics, University of Nottingham, UK; ${ }^{b}$ World Bank and University of \\ Minho, Portugal \\ (Received February 2007; final version received September 2007)

\begin{abstract}
We investigate the choice of regime amongst hard pegs, soft pegs, managed floats and independent floats for a panel of developing countries. There is evidence of a matched ordering of regimes and country characteristics. We find some evidence for the 'balance sheet' hypothesis that foreign liabilities in the banking system and foreign debt are associated with less exchange rate flexibility, particularly when a 'de facto' regime classification is used. Easily the best predictor of a country's current regime is its regime in the previous year.
\end{abstract}

Keywords: exchange rate regimes; developing countries

\section{Introduction}

The match between theory and empirics in the choice of exchange rate regime is historically weak, in the sense that empirical research on the choice of exchange rate regime has tended to find only limited support for theoretical models (e.g. Collins 1996; Edwards 1996; Poirson 2001; Rizzo 1998), although Levy-Yeyati et al. (2006) claim otherwise for a simple binary model of pegs versus floats. The issue is, however, worth re-examining in view of recent theoretical developments. Frankel (2005) argues that devaluations are contractionary in emerging markets mainly because of the effects of exchange rate movements on the balance sheets of both the private and the public sectors in countries that borrow in foreign currency. This may be an important motivation for restricting exchange-rate flexibility in emerging markets (Calvo and Reinhart 2002; Hausmann et al. 2001). Honig (2005) presents empirical evidence that liability dollarisation is associated with less exchange rate flexibility.

A second issue is the specification of the dependent variable. In the 1990s, the traditional binary split (fixed versus flexible) came under challenge from the thesis that there is a critical difference between the

*Corresponding author. Email: michael.bleaney@nottingham.ac.uk 
'poles' (independent floats and 'hard' pegs) and 'intermediate' exchange rate regimes (managed floats and 'soft' or adjustable pegs), because the latter offer too much of a one-way bet to speculators in a world of greatly increased capital mobility (Fischer 2001; Obstfeld and Rogoff 1995). The Washington consensus of the 1990s seemed to advocate a flight to the extremes, at least for emerging markets and more developed economies (Williamson 2000), although it is not clear that intermediate regimes have been abandoned to any significant extent in practice (Masson 2001). Nevertheless, this raises the issue of whether intermediate regimes occur in countries with truly intermediate characteristics, or rather in countries that are polar in some respects (e.g. in being particularly vulnerable to currency crises). We address this issue explicitly.

Third, the actual behaviour of exchange rates is occasionally markedly different from the official classification of an exchange rate regime, particularly in the case of developing countries (Bubula and Ötker-Robe 2002; LevyYeyati and Sturzenegger 2005; Reinhart and Rogoff 2004; Shambaugh 2004). Alternative de facto classifications have limitations of their own, and sometimes show disturbingly little correlation with the official classification (and with each other) outside the obvious cases. The use of purely statistical methods that entirely ignore official claims about the regime in force is questionable (Genberg and Swoboda 2005). We check our results for the official classification with that of Bubula and Ötker-Robe (2002), which backdates the IMF's post-1999 practice of checking the official claims about the exchange rate regime against other documentary and statistical evidence.

We estimate a model of regime choice that allows for four categories of regime, and we test whether our results are sensitive to different classification methods. The model specification emphasises measures of potential balance sheet effects (foreign debt, foreign-currency liabilities in the banking system), but also a variety of controls (country size, openness and inflation, financial development, per capita GDP, regional dummies). ${ }^{2}$ We use a sample of developing countries (excluding transition economies) over the period 1990 to 2000. We exclude advanced countries because of the likelihood of introducing structural instability (for example, export price volatility and balance sheet effects are much less likely to be of significance in advanced countries), and also because the correct classification of the European Monetary System is open to doubt. We also exclude transition economies precisely because they were in transition at this time.

\section{Data and methodology}

We gathered information on the exchange rate regime for 81 developing countries (listed in the Appendix) for the years 1990-2000. We constructed a data set based on IMF classifications reported in the Annual Report of Exchange Arrangements and Exchange Restrictions. The IMF classification 
is based on the official description provided by its members to the IMF. In order to minimise possible endogeneity problems, exchange rate regimes are observed on 31 December, whereas the explanatory variables are averages over the calendar year up to that date. ${ }^{3}$

Each of these classifications contains more than four categories. No aggregation of floats was required, since they were already divided into only two categories (independent floats and managed floats). Pegs were aggregated as follows:

(i) Hard Peg regimes: Currency Boards and No Separate Legal Tender;

(ii) Soft Peg regimes: Pegs to a Single Currency, Peg to a Basket of Currencies and Crawling Pegs and Bands.

To test the robustness of the results, we also use a de facto classification that adjusts for cases where the actual behaviour of the exchange rate is inconsistent with the declared regime - that of Bubula and Ötker-Robe (2002), henceforth called the BR classification. This classification takes account of documentary evidence, where this indicates that the regime is different from that officially declared, and of the statistical behaviour of the nominal exchange rate (for example, if it remains within a narrow range against some currency, the episode is classified as a peg). The main effect of the adjustment, as Table 1 shows, is that there are many fewer independent floats and many more soft pegs, which is consistent with the idea that developing countries are fearful of floating (Calvo and Reinhart 2002). Note that, in the de facto classification, intermediate regimes are significantly more frequent, and polar regimes significantly less frequent, than in the declared classification.

There are alternative de facto classifications that use somewhat different methodologies. That of Levy-Yeyati and Sturzenegger (2005) is arguably over-mechanical (for example, classifying large devaluations as floats) and generates an unrealistically large number of regime switches. Reinhart and Rogoff (2004) focus on parallel-market exchange rates, which reflect both the official rate and a variety of exogenous factors. This renders the economic meaning of any estimated regime choice model based on their data somewhat unclear, because it is difficult to define in exactly what sense a

Table 1. Distribution of regimes (\%).

\begin{tabular}{lcc}
\hline Regime & Declared (IMF) Classification & De facto (BR) Classification \\
\hline Hard peg & 20.9 & 20.7 \\
Soft peg & 34.6 & 47.2 \\
Managed float & 18.9 & 20.8 \\
Independent float & 25.9 & 11.3 \\
\hline
\end{tabular}


regime identified from exchange rates in the parallel market may be deemed to have been chosen by the authorities.

We turn now to the regression specification. Recent work has focused on the balance sheet effects of currency movements in countries where liabilities are mostly denominated in foreign currency. A sharp devaluation worsens balance sheets, making debts harder to service and tightening credit constraints for private and public agents that produce non-tradable goods (Choi and Cook 2004; Honig 2005; Morón and Winkelried 2005). ${ }^{4}$ To capture balance sheet effects, we use two variables - the ratio of external debt to GDP, and the ratio of foreign-currency liabilities in the deposit money banks (International Financial Statistics, line 26c) to GDP. Larger values of these variables are expected to be associated with a greater probability of pegging.

Beyond this, we include a variety of controls suggested by Optimum Currency Area (OCA) theory: size, openness, inflation, the degree of economic development, and the degree of financial integration.

Size is often measured by GDP (usually in natural logarithms), but it seems unduly restrictive to assume that the two components of this (population and GDP per capita) should have the same coefficient, so we keep them separate. ${ }^{5}$

We measure openness by the ratio of imports plus exports to GDP. For given country size, greater openness means that nominal exchange rate changes are more likely to be offset by movements in the domestic price level, but it also implies a greater sensitivity of output to external shocks, so the expected sign of the effect is uncertain.

We transform the percentage inflation rate $(\pi)$ as $[100 \pi /(100+\pi)]$ to reduce the effect of high-inflation outliers. A higher inflation rate (relative to trading partners) implies a greater frequency of adjustment of a peg, and therefore, if adjustments are costly, a greater incentive to avoid them by choosing a floating regime.

Countries with greater financial development are likely to have more liquid financial markets, in the absence of which flexible exchange rates may be excessively volatile. Consequently, we expect greater financial depth to be associated with a greater probability of floating. We proxy financial depth by the ratio of quasi-money (IFS, line 35) to money (IFS, line 34).

Ideally, in order to allow for shifts in average values of variables over time (including the popularity of floating), it would be desirable to include year dummies in the regression. Since the algorithm failed to converge when year dummies were present, we include a time trend instead. It should be noted that the coefficient of the time trend cannot be interpreted simply as a shift in the relative popularity of different regimes over time, because it adjusts to ensure that any time trend in the predicted values matches the time trend in the dependent variable. 
In the case of an ordered probit with four outcomes, the equation that we estimate is as follows:

$$
\begin{aligned}
& \operatorname{Pr}(E R R=1 / x)=\Phi\left(-x^{\prime} \beta\right) \\
& \operatorname{Pr}(E R R=2 / x)=\Phi\left(\mu_{1}-x^{\prime} \beta\right)-\Phi\left(-x^{\prime} \beta\right) \\
& \operatorname{Pr}(E R R=3 / x)=\Phi\left(\mu_{2}-x^{\prime} \beta\right)-\Phi\left(\mu_{1}-x^{\prime} \beta\right) \\
& \operatorname{Pr}(E R R=4 / x)=1-\Phi\left(\mu_{2}-x^{\prime} \beta\right) \\
& x=(1, D E B T, F L, P O P, Y P C, O P E, I N F, Q M M, T I M E)
\end{aligned}
$$

where $E R R$ is an indicator variable for the exchange rate regime, $\Phi$ is the cumulative normal distribution, $D E B T$ is the ratio of external debt to GDP, $F L$ is the ratio of foreign liabilities in the banking system to GDP, $P O P$ is the log of population, YPC is the log of per capita GDP, $O P E$ is the ratio of international trade to GDP, $I N F$ is the inflation rate (transformed as described above), $Q M M$ is the ratio of quasi-money to money, TIME is a time trend, and $\beta$ is a vector of coefficients. We begin by estimating binary probits, which are a special case of equation (1) with only two outcomes. Since some of the independent variables are non-stationary, estimated coefficients may be biased in limited samples, even though they are consistent. Park and Phillips (2000) show that non-stationarity slows down the rate of convergence in the estimates of coefficients and marginal effects, even though Wald tests of restrictions still have asymptotic chisquared distributions.

\section{Estimation results}

With multiple regime categories, an attractive approach is to order the regimes from the least flexible to the most flexible, and to estimate an ordered probit model. Before doing this, however, it is important to check that intermediate regimes are genuinely intermediate. We address this problem in the following way. We first show that polar regimes are indeed more different from each other than are intermediate regimes. Then we estimate a multinomial model and investigate whether the pattern of regression coefficients is consistent with a natural ordering of regimes from least to most flexible.

We begin by estimating a traditional probit model, dividing the sample into floats and pegs. Potentially there are 1122 observations (11 years, 102 countries), but data availability for the independent variables reduces the usable sample to 835. Table 2 shows the results for both the declared (IMF) classification and the de facto (BR) classification. The table suggests that floaters have on average a larger population, lower per capita incomes, higher inflation, greater openness, and (somewhat more ambiguously) less external debt and fewer foreign-currency liabilities in the banking system. 
Table 2. The probability of choosing a floating regime 1990-2000.

\begin{tabular}{|c|c|c|}
\hline Independent variables & $\begin{array}{c}\text { Declared (IMF) } \\
\text { Classification }\end{array}$ & $\begin{array}{l}\text { De facto (BR) } \\
\text { Classification }\end{array}$ \\
\hline Constant & $\begin{array}{l}-5.29 * * \\
(-6.26)\end{array}$ & $\begin{array}{l}-4.55^{* *} \\
(-5.43)\end{array}$ \\
\hline External debt/GDP & $\begin{array}{l}-0.044 \\
(-1.67)\end{array}$ & $\begin{array}{l}-0.044^{*} \\
(-2.25)\end{array}$ \\
\hline $\begin{array}{c}\text { Foreign currency liabilities } \\
\text { in banking system/GDP }\end{array}$ & $\begin{array}{l}-0.915^{*} \\
(-2.45)\end{array}$ & $\begin{array}{l}-0.515 \\
(-1.16)\end{array}$ \\
\hline Log population & $\begin{array}{l}0.135^{* *} \\
(7.81)\end{array}$ & $\begin{array}{l}0.102 * * \\
(6.73)\end{array}$ \\
\hline Log per capita GDP & $\begin{array}{l}-0.0907 * * \\
(-3.25)\end{array}$ & $\begin{array}{l}-0.0970 * * \\
(-4.05)\end{array}$ \\
\hline $\begin{array}{l}\text { Inflation }(\%) \\
{[100 \pi /(100+\pi)]}\end{array}$ & $\begin{array}{l}0.0128 * * \\
(5.30)\end{array}$ & $\begin{array}{l}0.0061 * * \\
(4.16)\end{array}$ \\
\hline Openness & $0.348 * *$ & $0.307 * *$ \\
\hline$[($ Exports + Imports $) / G D P]$ & $(4.63)$ & $(4.81)$ \\
\hline Quasi-money/money & $\begin{array}{l}0.0037 \\
(0.21)\end{array}$ & $\begin{array}{l}-0.0039 \\
(-0.25)\end{array}$ \\
\hline Time & $\begin{array}{l}0.022 * * \\
(3.31)\end{array}$ & $\begin{array}{l}0.031^{* *} \\
(5.59)\end{array}$ \\
\hline Sample size & 835 & 835 \\
\hline Pseudo-R-squared & 0.197 & 0.169 \\
\hline$\%$ correct predictions & 74 & 72 \\
\hline Wald statistic $\left(\chi_{11}^{2}\right)$ & $176^{* *}$ & $153 * *$ \\
\hline [p-value] & {$[0.000]$} & {$[0.000]$} \\
\hline
\end{tabular}

Notes: Coefficients are marginal effects estimated at the mean value of the independent variable. Figures in parentheses are the associated $t$-statistics. ${ }^{* *}$ significant at the 0.01 level; *significant at the 0.05 level. Three area dummies (Asia, Western Hemisphere, and Middle East and Europe) are also included in the regression. The Wald statistic is the test of the significance of the whole regression.

The regional dummies (not shown in the table) indicate that there is a greater propensity to float in the western hemisphere. Although there are more pegs in the de facto classification, the two regressions are remarkably similar overall.

We next test whether the picture is significantly different if we split the sample into polar and intermediate regimes. In Table 3, the first column shows a regression for the probability of floating, according to the IMF classification, given that a country has a polar regime (independent float or hard peg). The second column shows the same regression, given that the country has an intermediate regime (managed float or soft peg). In the first column all the coefficients are significant, $84 \%$ of the predictions are correct and the pseudo-R-squared is 0.47 . In the second column, despite the slightly larger sample, many of the coefficients are insignificant, only $69 \%$ of the predictions are correct, and the pseudo-R-squared is only 0.11 . The third 
Table 3. The probability of choosing a float (polar and intermediate regimes separately).

\begin{tabular}{|c|c|c|c|c|}
\hline \multirow[b]{2}{*}{ Independent variables } & \multicolumn{2}{|c|}{$\begin{array}{l}\text { Declared (IMF) } \\
\text { Classification }\end{array}$} & \multicolumn{2}{|c|}{$\begin{array}{l}\text { De facto (BR) } \\
\text { Classification }\end{array}$} \\
\hline & $\begin{array}{l}\text { Polar } \\
\text { regimes }\end{array}$ & $\begin{array}{l}\text { Intermediate } \\
\text { regimes }\end{array}$ & $\begin{array}{l}\text { Polar } \\
\text { regimes }\end{array}$ & $\begin{array}{l}\text { Intermediate } \\
\text { regimes }\end{array}$ \\
\hline Constant & $\begin{array}{l}-10.2^{* *} \\
(-6.50)\end{array}$ & $\begin{array}{l}-5.30 * * \\
(-4.46)\end{array}$ & $\begin{array}{l}-8.78 * * \\
(-4.41)\end{array}$ & $\begin{array}{l}-4.60 * * \\
(-4.24)\end{array}$ \\
\hline External debt/GDP & $\begin{array}{l}-0.087 \\
(-0.99)\end{array}$ & $\begin{array}{l}-0.001 \\
(-0.02)\end{array}$ & $\begin{array}{l}-0.195^{* *} \\
(-3.01)\end{array}$ & $\begin{array}{l}-0.029 \\
(-1.32)\end{array}$ \\
\hline $\begin{array}{l}\text { Foreign currency } \\
\text { liabilities in banking } \\
\text { system/GDP }\end{array}$ & $\begin{array}{l}-1.96^{* * *} \\
(-2.73)\end{array}$ & $\begin{array}{l}-0.505 \\
(-1.28)\end{array}$ & $\begin{array}{l}-3.01^{* *} \\
(-3.27)\end{array}$ & $\begin{array}{c}0.490 \\
(1.28)\end{array}$ \\
\hline Log population & $\begin{array}{l}0.247 * * \\
(7.30)\end{array}$ & $\begin{array}{l}0.102^{* *} \\
(4.86)\end{array}$ & $\begin{array}{l}0.192 * * \\
(5.27)\end{array}$ & $\begin{array}{l}0.104 * * \\
(5.84)\end{array}$ \\
\hline Log per capita GDP & $\begin{array}{l}-0.175^{* *} \\
(-3.67)\end{array}$ & $\begin{array}{l}-0.002 \\
(-0.05)\end{array}$ & $\begin{array}{l}-0.197 * * \\
(-3.70)\end{array}$ & $\begin{array}{l}-0.080 \\
(-2.78)\end{array}$ \\
\hline Inflation $(\%)$ & $0.0339 * *$ & 0.0048 & $0.0264 * *$ & -0.0002 \\
\hline$[100 \pi /(100+\pi)]$ & $(8.21)$ & $(1.70)$ & $(5.80)$ & $(-0.10)$ \\
\hline Openness & $0.766 * *$ & 0.146 & $0.720 * *$ & $0.268 * *$ \\
\hline $\begin{array}{l}\text { [(Exports }+ \text { Imports }) / \\
\text { GDP }]\end{array}$ & $(4.54)$ & $(1.65)$ & $(3.97)$ & $(3.82)$ \\
\hline Quasi-money/money & $\begin{array}{l}0.0933 * * \\
(2.98)\end{array}$ & $\begin{array}{l}-0.0289 \\
(-1.45)\end{array}$ & $\begin{array}{l}0.0966^{* * *} \\
(2.92)\end{array}$ & $\begin{array}{l}-0.0220 \\
(-1.23)\end{array}$ \\
\hline Time & $\begin{array}{l}0.030^{* *} \\
(3.15)\end{array}$ & $\begin{array}{l}0.020 * * \\
(2.42)\end{array}$ & $\begin{array}{l}0.036^{* *} \\
(3.59)\end{array}$ & $\begin{array}{l}0.023^{* *} \\
(3.42)\end{array}$ \\
\hline Sample size & 422 & 411 & 291 & 544 \\
\hline Pseudo-R-squared & 0.468 & 0.108 & 0.433 & 0.150 \\
\hline$\%$ correct predictions & 84 & 69 & 83 & 73 \\
\hline $\begin{array}{l}\text { Wald statistic }\left(\chi_{11}^{2}\right) \\
{[p \text {-value }]}\end{array}$ & $\begin{array}{l}190 * * \\
{[0.000]}\end{array}$ & $\begin{array}{l}58.6^{* *} \\
{[0.000]}\end{array}$ & $\begin{array}{l}96.3 * * \\
{[0.000]}\end{array}$ & $\begin{array}{l}83.9 * * \\
{[0.000]}\end{array}$ \\
\hline $\begin{array}{l}\text { Chow statistic } \\
\text { [p-value] }\end{array}$ & \multicolumn{2}{|c|}{$\begin{array}{c}\chi^{2}(9)=130.1^{* *} \\
{[0.000]}\end{array}$} & \multicolumn{2}{|c|}{$\begin{array}{c}\chi+{ }^{2}(9)=141.5^{* *} \\
{[0.000]}\end{array}$} \\
\hline
\end{tabular}

Notes: Coefficients are marginal effects estimated at the mean value of the independent variable. **significant at the 0.01 level; *significant at the 0.05 level. Figures in parentheses are $t$-statistics. Three area dummies (Asia, Western Hemisphere, and Middle East and Europe) are also included in the regression. Polar regimes are independent floats and hard pegs; intermediate regimes are managed floats and soft pegs. The Wald statistic is the test of the significance of the whole regression. The Chow test was based on regressions omitting the area dummies.

and fourth columns of Table 3 show the equivalent regressions for the de facto classification. Compared with the IMF classification, in the BR classification another 133 observations (15.9\% of the sample) are classified as intermediate, which makes intermediate regime observations nearly twice as frequent as polar regime observations, and rather more coefficients are significant in the intermediate sample than is the case with the IMF 
classification. The difference between the pseudo-R-squareds is nevertheless still large ( 0.43 and 0.15 respectively), and the proportion of correct predictions again favours the polar sample ( $83 \%$ compared with $73 \%)$. A Chow test reveals that the null hypothesis of equality of coefficients between the two sub-samples is decisively rejected in each case.

The results in Table 3 show that there is clearly some concordance between the regression for polar regimes and that for intermediate regimes. In the case of the majority of coefficients that matter (eight out of eight for the IMF classification, and five out of eight for the BR classification, ignoring the constant), there is agreement of the signs of the coefficients between the polar and intermediate sub-samples. Moreover, in every single case, the coefficient in the polar sub-sample is larger in absolute value. This suggests a similarity in the factors that determine the choice between a float and a peg, and also that polar regimes have more extreme characteristics.

Table 3 also shows that countries on managed floats are clearly empirically distinguishable from those on soft pegs (the Wald statistic is smaller in the intermediate regime regression than in the polar regime regression, but still highly significant). Managed floaters tend to be more populous than soft peggers - this coefficient is significant in both the IMF and BR classifications. According to the de facto classification only, countries on managed floats also tend to be poorer and more open to international trade. The results in Table 3 are approximately what one would expect if there is an ordering of regimes from independent floats at one end of the spectrum to hard pegs at the other. Countries on polar regimes have more extreme characteristics than countries on intermediate regimes, and are more different from countries at the opposite pole than from intermediate regimes, but different types of intermediate regime also have different characteristics. The much better fit to the data in the case of the sample of polar regimes is consistent with this hypothesis. For the sake of completeness, a multinomial model of the choice between all four regimes is shown in Appendix Table A1.

A significant consideration is that treating the data as a panel tends to exaggerate the statistical significance of explanatory variables because exchange rate regimes are themselves highly persistent. If a country is observed to be in one regime in year $t$, it is very likely to be in it in year $t+1$ as well. If explanatory variables are themselves persistent (as they are in most cases), there will be a significant element of pseudo-replication in a panel there are fewer truly independent observations than are claimed. One way to deal with this is to give up trying to explain regimes and just to investigate regime switches, as in Masson and Ruge-Murcia (2005). Alternatively one could treat the 11 years as 11 cross-sections, estimate the model for each year separately and average the resulting $t$-statistics (since to choose any one year would be arbitrary). This would be going to the other extreme, because it throws away the whole time series dimension. An appealing compromise is to 
add the lagged exchange rate regime to the regression, since this controls for regime persistence while retaining the richness of the panel data. Since there is evidence of an ordering of regimes, it seems most parsimonious to do this within the framework of an ordered probit model (hard peg $=1$, soft peg $=2$, managed float $=3$, independent float $=4){ }^{6}$

Table 4 reports the results of this exercise. Although the dependent variable is ordered, we include three separate dummies for the lagged regime

Table 4. An ordered probit model including the lagged regime.

\begin{tabular}{|c|c|c|}
\hline Independent variables & $\begin{array}{c}\text { Declared (IMF) } \\
\text { Classification }\end{array}$ & $\begin{array}{l}\text { De facto (BR) } \\
\text { Classification }\end{array}$ \\
\hline External debt/GDP & $\begin{array}{l}-0.045 \\
(-0.75)\end{array}$ & $\begin{array}{l}-0.090^{*} \\
(-2.32)\end{array}$ \\
\hline $\begin{array}{l}\text { Foreign currency liabilities } \\
\text { in banking system/GDP }\end{array}$ & $\begin{array}{l}-0.602 \\
(-0.79)\end{array}$ & $\begin{array}{l}-2.09^{*} \\
(-2.19)\end{array}$ \\
\hline Log population & $\begin{array}{l}0.0694 * \\
(2.06)\end{array}$ & $\begin{array}{l}0.0752^{*} \\
(2.24)\end{array}$ \\
\hline Log per capita GDP & $\begin{array}{l}-0.110 \\
(-1.50)\end{array}$ & $\begin{array}{l}-0.183^{* *} \\
(-2.78)\end{array}$ \\
\hline Inflation $(\%)$ & 0.0083 & 0.0077 \\
\hline$[100 \pi /(100+\pi)]$ & $(1.24)$ & $(1.65)$ \\
\hline Openness & 0.229 & $0.375^{* *}$ \\
\hline [(Exports + Imports)/GDP] & $(1.45)$ & $(2.60)$ \\
\hline Quasi-money/money & $\begin{array}{l}0.0143 \\
(0.38)\end{array}$ & $\begin{array}{l}-0.0461 \\
(-1.20)\end{array}$ \\
\hline Time & $\begin{array}{l}-0.0212 \\
(-1.32)\end{array}$ & $\begin{array}{l}0.0719 \text { ** } \\
(4.09)\end{array}$ \\
\hline Lagged hard peg dummy & $\begin{array}{l}-10.99^{* *} \\
(-42.2)\end{array}$ & $\begin{array}{l}-11.97^{* *} \\
(-36.8)\end{array}$ \\
\hline Lagged managed float dummy & $\begin{array}{l}1.42 * * \\
(9.37)\end{array}$ & $\begin{array}{l}1.16^{* *} \\
(9.97)\end{array}$ \\
\hline Lagged independent float dummy & $\begin{array}{l}3.38^{* *} \\
(13.7)\end{array}$ & $\begin{array}{l}2.23^{* *} \\
(9.95)\end{array}$ \\
\hline Ancillary parameter: cut 1 & $\begin{array}{c}-1.78 \\
{[\text { s.e. }=0.856]}\end{array}$ & $\begin{array}{c}-2.03 \\
{[\text { s.e. }=0.823]}\end{array}$ \\
\hline Ancillary parameter: cut 2 & $\begin{array}{c}1.36 \\
{[\text { s.e. }=0.865]}\end{array}$ & $\begin{array}{c}1.22 \\
{[\text { s.e. }=0.859]}\end{array}$ \\
\hline Ancillary parameter: cut 3 & $\begin{array}{c}2.72 \\
\text { [s.e. }=0.893]\end{array}$ & $\begin{array}{c}2.51 \\
{[\text { s.e. }=0.883]}\end{array}$ \\
\hline Sample size & 835 & 834 \\
\hline Pseudo-R-squared & 0.654 & 0.561 \\
\hline Wald statistic $\left(\chi_{11}^{2}\right)$ & $2568 * *$ & $2162 * *$ \\
\hline [p-value] & {$[0.000]$} & {$[0.000]$} \\
\hline
\end{tabular}

Notes: Figures in parentheses are $t$-statistics. ${ }^{* *}$ significant at the 0.01 level; *significant at the 0.05 level. Dependent variable: hard $p e g=1$, soft peg $=2$, managed float $=3$, independent float $=4$. 'Cut 1', 'Cut 2' and 'Cut 3' are the estimated boundaries between regimes for the fitted values of the regression. The Wald statistic is the test of the significance of the whole regression. 
(the omitted category is a soft peg). These are all highly significant, which confirms how persistent exchange rate regimes tend to be. Otherwise, results are somewhat different for the official (IMF) and de facto (BR) classifications. In the IMF classification, the only other significant variable is population, and its coefficient is positive, implying that larger countries are more likely to have flexible regimes. In the BR classification, two variables have a significant positive association with regime flexibility (population and openness) and three have a significant negative association (per capita GDP, external debt and foreign liabilities in the banking system).

These results imply support for the idea that fear of the impact of exchange rate movements on agents' balance sheets induces countries to (attempt to) limit exchange rate flexibility. Both higher external debt and more foreigncurrency liabilities in the banking system are associated with less flexibility.

Table 4 confirms that countries on hard pegs have particularly well defined characteristics. The estimated boundary between hard pegs and soft pegs

Table 5. Marginal effects of the ordered probit model for the BR Classification in Table 4.

\begin{tabular}{|c|c|c|c|c|}
\hline Regime & $\begin{array}{l}\text { Hard } \\
\text { peg }\end{array}$ & $\begin{array}{l}\text { Other } \\
\text { peg }\end{array}$ & $\begin{array}{l}\text { Managed } \\
\text { float }\end{array}$ & $\begin{array}{l}\text { Independent } \\
\text { float }\end{array}$ \\
\hline Ordered probit value & 1.0 & 2.0 & 3.0 & 4.0 \\
\hline Fitted probability & 0.405 & 0.593 & 0.001 & 0.000 \\
\hline External debt/GDP & $0.035 *$ & $-0.035^{*}$ & -0.000 & -0.000 \\
\hline $\begin{array}{r}\text { Foreign currency } \\
\text { liabilities/GDP }\end{array}$ & $\begin{array}{l}0.811 * \\
(2.23)\end{array}$ & $\begin{array}{l}-0.803 * \\
(-2.23)\end{array}$ & $(-0.009 *$ & $\begin{array}{r}-0.000 \\
(-1.34)\end{array}$ \\
\hline Log population & $\begin{array}{l}-0.0292 * \\
(-2.27)\end{array}$ & $\begin{array}{l}0.0288^{*} \\
(2.27)\end{array}$ & $\begin{array}{l}0.0003^{*} \\
(1.97)\end{array}$ & $\begin{array}{c}0.000 \\
(1.37)\end{array}$ \\
\hline Log per capita GDP & $\begin{array}{l}0.0709 * \\
(2.64)\end{array}$ & $\begin{array}{l}-0.0701^{*} \\
(-2.65)\end{array}$ & $\begin{array}{l}-0.0008^{*} \\
(-2.10)\end{array}$ & $\begin{array}{l}-0.000 \\
(-1.29)\end{array}$ \\
\hline Inflation $(\%)$ & -0.0030 & 0.0030 & 0.0000 & 0.0000 \\
\hline$[100 \pi /(100+\pi)]$ & $(-1.66)$ & $(1.66)$ & $(1.53)$ & $(1.14)$ \\
\hline Openness & $\begin{array}{l}-0.145^{*} \\
(-2.53)\end{array}$ & $\begin{array}{l}0.144^{*} \\
(2.53)\end{array}$ & $\begin{array}{l}0.002 * \\
(2.07)\end{array}$ & $\begin{array}{r}0.000 \\
(1.34)\end{array}$ \\
\hline Quasi-money/money & $\begin{array}{l}0.0179 \\
(1.22)\end{array}$ & $\begin{array}{l}-0.0177 \\
(-1.22)\end{array}$ & $\begin{array}{l}-0.0002 \\
(-1.21)\end{array}$ & $\begin{array}{l}-0.0000 \\
(-1.05)\end{array}$ \\
\hline Time & $\begin{array}{l}-0.0279 * * \\
(-4.29)\end{array}$ & $\begin{array}{l}0.0276 * * \\
(4.28)\end{array}$ & $\begin{array}{l}0.0003^{* *} \\
(3.19)\end{array}$ & $\begin{array}{l}0.0000 \\
(1.57)\end{array}$ \\
\hline $\begin{array}{l}\text { Lagged hard peg } \\
\text { dummy }\end{array}$ & $\begin{array}{l}0.998 * * \\
(683.0)\end{array}$ & $\begin{array}{l}-0.625^{* *} \\
(-28.8)\end{array}$ & $\begin{array}{l}-0.321^{* *} \\
(-16.1)\end{array}$ & $\begin{array}{l}-0.053^{* *} \\
(-4.51)\end{array}$ \\
\hline $\begin{array}{l}\text { Lagged managed } \\
\text { float dummy }\end{array}$ & $\begin{array}{l}-0.375^{* *} \\
(-8.73)\end{array}$ & $\begin{array}{l}0.357^{* *} \\
(8.83)\end{array}$ & $\begin{array}{l}0.018^{* *} \\
(4.53)\end{array}$ & $\begin{array}{l}0.000^{*} \\
(2.44)\end{array}$ \\
\hline $\begin{array}{l}\text { Lagged independent } \\
\text { float dummy }\end{array}$ & $\begin{array}{l}-0.493^{* *} \\
(-7.62)\end{array}$ & $\begin{array}{l}0.344^{* *} \\
(4.17)\end{array}$ & $\begin{array}{l}0.140^{* *} \\
(3.72)\end{array}$ & $\begin{array}{l}0.010^{*} \\
(2.55)\end{array}$ \\
\hline
\end{tabular}

Notes: Figures in parentheses are $t$-statistics. ${ }^{* *}$ significant at the 0.01 level; *significant at the 0.05 level. Dependent variable: hard peg $=1$, soft peg $=2$, managed float $=3$, independent float $=4$. 
(cut 1) is further from the estimated boundary between managed floats and soft pegs (cut 2) than is the estimated boundary between independent floats and managed floats (cut 3). The distances are more than two and about 1.5 standard errors respectively. The numbers in Table 4 are coefficients rather than marginal effects. For the BR classification only, estimated marginal effects for each regime, together with the appropriate $t$-ratios, are shown in Table 5. The estimated probability of any type of float is very small $(0.1 \%)$.

\section{Conclusions}

We have tested for balance sheet effects in the choice of exchange rate regime in developing countries. Countries on polar exchange rate regimes tend to have more extreme characteristics than those on intermediate regimes. Much the best predictor of an exchange rate regime is that in force in the previous year, and, once this is allowed for, our model has virtually no explanatory power according to the official classification. Using the de facto classification, however, results are somewhat different. In this classification, soft pegs are more numerous and independent floats less numerous than in the official classification. Both external debt and foreign liabilities in the banking system are associated with less exchange rate flexibility, which is consistent with the balance sheet hypothesis. A larger population, a lower per capita GDP and greater openness to international trade are associated with greater flexibility.

\section{Notes}

1. The views expressed here are those of the authors and do not represent the opinions of the World Bank or of its Executive Directors or of the countries that they represent.

2. Wickham (1985) surveys the earlier literature on the choice of exchange rate regime.

3. This does not entirely remove endogeneity concerns for variables that are themselves persistent, such as the inflation rate.

4. Panama has significantly larger values of the ratio of foreign-currency liabilities in deposit money banks to GDP than other countries. Since Panama is a hardpeg country that has used the US dollar for a long time, we adjusted this ratio to zero for Panama, to avoid biasing the results in the direction which we expect that exposure of banks' balance sheets to currency movements causes countries to prefer less exchange rate flexibility.

5. Where not stated, the source of the data is World Development Indicators.

6. An alternative is to estimate a multinomial probit model, but the algorithm failed to converge.

\section{References}

Bubula, A., and I. Ötker-Robe. 2002. The evolution of exchange rate regimes since 1990: evidence from de facto policies. IMF Working Paper no. 02/155.

Calvo, G., and C.M. Reinhart. 2002. Fear of floating. Quarterly Journal of Economics 117, no. 2: 379-408. 
Choi, W.G., and D. Cook. 2004. Liability dollarization and the bank balance sheet channel. Journal of International Economics 64, no. 2: 247-75.

Collins, S. 1996. On becoming more flexible: exchange rate regimes in Latin America and the Caribbean. Journal of Development Economics 51, no. 1: 117-38.

Edwards, S. 1996. The determinants of the choice between fixed and flexible exchange rate regimes. NBER Working Paper no. 5756.

Fischer, S. 2001. Exchange rate regimes: is the bipolar view correct? Journal of Economic Perspectives 15, no. 2: 3-24.

Frankel, J.A. 2005. Contractionary currency crashes in developing countries. IMF Staff Papers 52, no. 2: 149-91.

Genberg, H., and A. Swoboda. 2005. Exchange rate regimes: does what countries say matter? IMF Staff Papers, 52 (Special Issue): 129-41.

Hausmann, R., U. Panizza, and E. Stein. 2001. Why do countries float the way they float? Journal of Development Economics 66, no. 2: 387-414.

Honig, A. 2005. Fear of floating and domestic liability dollarization. Emerging Markets Review 6, no. 3: 289-307.

Levy-Yeyati, E. and F. Sturzenegger. 2005. Classifying exchange rate regimes: deeds versus words. European Economic Review 49: 1603-35.

Levy-Yeyati, E., F. Sturzenegger, and I. Reggio. 2006. On the endogeneity of exchange rate regimes. Faculty Research Working Paper no. 06-047, John F. Kennedy School of Government, Harvard University.

Masson, P. 2001. Exchange rate regime transitions. Journal of Development Economics 64, no. 2: 571-86.

Masson, P., and F. Ruge-Murcia. 2005. Explaining the transition between exchange rate regimes. Scandinavian Journal of Economics 107: 261-78.

Morón, E., and E. Winkelried. 2005. Monetary policy rules for financially vulnerable economies. Journal of Development Economics 76, no. 1: 23-51.

Obstfeld, M., and K. Rogoff. 1995. The mirage of fixed exchange rates. Journal of Economic Perspectives 9, no. 4: 73-96.

Park, J.Y., and P.C.B. Phillips. 2000. Non-stationary binary choice. Econometrica 68, no. 5: 1249-80.

Poirson, H. 2001. How do countries choose their exchange rate regime? IMF Working Paper no. 01/46.

Reinhart, C.M., and K. Rogoff. 2004. The modern history of exchange rate arrangements: a reinterpretation. Quarterly Journal of Economics 119, no. 1: 148.

Rizzo, J.-M. 1998. The economic determinants of the choice of an exchange rate regime: a probit analysis. Economics Letters 59, no. 3: 283-7.

Shambaugh, J. 2004. The effect of fixed exchange rates on monetary policy. Quarterly Journal of Economics 119: 301-52.

Wickham, P. 1985. The choice of exchange rate regime in developing countries: a survey of literature. International Monetary Fund Staff Papers 32, no. 2: 248-89.

Williamson, J. 2000. Exchange Rate Regimes for Emerging Markets: Reviving the Intermediate Option. Washington, DC: Institute for International Economics. 


\section{Appendix}

The following countries are included in the sample:

$\begin{array}{llll}\text { Algeria } & \text { Argentina } & \text { Bangladesh } & \text { Belize } \\ \text { Benin } & \text { Botswana } & \text { Brazil } & \text { Burkina Faso } \\ \text { Cameroon } & \text { Cape Verde } & \text { Central Afr. Rep. } & \text { Chad } \\ \text { Chile } & \text { Colombia } & \text { Congo, Dem. Rep. } & \text { Congo, Rep. } \\ \text { Costa Rica } & \text { Côte d'Ivoire } & \text { Dominica } & \text { Dominican Rep. } \\ \text { Ecuador } & \text { Egypt } & \text { El Salvador } & \text { Ethiopia } \\ \text { Fiji } & \text { Gabon } & \text { Gambia } & \text { Ghana } \\ \text { Grenada } & \text { Guatemala } & \text { Guinea-Bissau } & \text { Guyana } \\ \text { Haiti } & \text { Honduras } & \text { India } & \text { Indonesia } \\ \text { Iran } & \text { Jamaica } & \text { Jordan } & \text { Kenya } \\ \text { Libya } & \text { Madagascar } & \text { Malawi } & \text { Malaysia } \\ \text { Maldives } & \text { Mali } & \text { Mauritania } & \text { Mauritius } \\ \text { Mexico } & \text { Morocco } & \text { Nepal } & \text { Nicaragua } \\ \text { Niger } & \text { Nigeria } & \text { Pakistan } & \text { Panama } \\ \text { Papua N.G. } & \text { Paraguay } & \text { Peru } & \text { Philippines } \\ \text { Rwanda } & \text { Senegal } & \text { Seychelles } & \text { Sierra Leone } \\ \text { South Africa } & \text { Sri Lanka } & \text { St. Lucia } & \text { St. Vincent \& Grenadines } \\ \text { Swaziland } & \text { Syria } & \text { Tanzania } & \text { Thailand } \\ \text { Togo } & \text { Trin. \& Tobago } & \text { Tunisia } & \text { Turkey } \\ \text { Uganda } & \text { Uruguay } & \text { Venezuela } & \text { Zambia } \\ \text { Zimbabwe } & & & \end{array}$


Table A1. A multinomial logistic model of regime choice.

\begin{tabular}{|c|c|c|}
\hline $\begin{array}{l}\text { Independent } \\
\text { variables }\end{array}$ & $\begin{array}{c}\text { Declared (IMF) } \\
\text { Classification }\end{array}$ & $\begin{array}{l}\text { De facto (BR) } \\
\text { Classification }\end{array}$ \\
\hline \multicolumn{3}{|l|}{ Hard Peg } \\
\hline Constant & $10.96 * *(5.94)$ & $11.91 * *(6.72)$ \\
\hline External debt/GDP & $0.138(1.01)$ & $0.128(1.04)$ \\
\hline F.c. liabilities/GDP & $1.08(0.70)$ & $1.45(0.95)$ \\
\hline Log population & $-0.487 * *(-6.20)$ & $-0.553^{* *}(-7.24)$ \\
\hline Log per capita GDP & $-0.179(-1.16)$ & $-0.209(-1.42)$ \\
\hline Inflation & $-0.140 * *(-5.37)$ & $-0.135^{* *}(-5.15)$ \\
\hline Openness & $-1.84 * *(-4.00)$ & $-1.84 * *(-3.95)$ \\
\hline Quasi-money/money & $-0.309 *(-2.40)$ & $-0.356^{* *}(-2.79)$ \\
\hline Time & $0.016(0.47)$ & $0.036(1.07)$ \\
\hline \multicolumn{3}{|l|}{ Managed Float } \\
\hline Constant & $-9.53^{* *}(-5.23)$ & $-6.07 * *(-4.07)$ \\
\hline External debt/GDP & $0.002(0.02)$ & $-0.175(-1.36)$ \\
\hline F.c. liabilities/GDP & $-3.56(-1.76)$ & $-3.44(-1.73)$ \\
\hline Log population & $0.477 * *(5.59)$ & $0.383^{* *}(5.25)$ \\
\hline Log per capita GDP & $0.039(0.33)$ & $-0.331 * *(-2.96)$ \\
\hline Inflation & $0.025 *(2.34)$ & $0.015(1.94)$ \\
\hline Openness & $0.738 *(2.06)$ & $1.41 * *(4.09)$ \\
\hline Quasi-money/money & $-0.074(-0.88)$ & $-1.06(-1.37)$ \\
\hline Time & $0.098(2.54)$ & $0.133^{* *}(3.97)$ \\
\hline \multicolumn{3}{|l|}{ Independent Float } \\
\hline Constant & $-2.51(-1.57)$ & $1.15(0.50)$ \\
\hline External debt/GDP & $-0.190(-1.54)$ & $-0.154(-1.52)$ \\
\hline F.c. liabilities/GDP & $-5.69 * *(-2.97)$ & $-12.09 *(-2.24)$ \\
\hline Log population & $0.221 * *(3.18)$ & $-0.031(-0.32)$ \\
\hline Log per capita GDP & $-0.331 * *(-2.62)$ & $-0.440 * *(-2.81)$ \\
\hline Inflation & $0.043 * *(4.22)$ & $0.030 * *(3.14)$ \\
\hline Openness & $0.355(1.06)$ & $-0.353(-0.76)$ \\
\hline Quasi-money/money & $0.074(0.96)$ & $-0.028(-0.29)$ \\
\hline Time & $0.119 * *(3.58)$ & $0.275^{* *}(6.56)$ \\
\hline Sample size & 835.0 & 834.0 \\
\hline Pseudo R-squared & 0.163 & 0.181 \\
\hline
\end{tabular}

Note: Omitted category is soft peg. Figures in brackets are z-statistics. 